\title{
THE EFFECTS OF LOW TEMPERATURE ON THE GROWTH AND TOTAL PROTEIN AMOUNT OF CHICKPEA (CICER ARIETINUM) SEEDLINGS
}

\author{
O. MUNZUROĞLU and F. ZENGIN \\ Biyoloji Bölümü, Fen-Edebiyat Fakültesi, Firat Üniversitesi, Elazı̆̆,Turkey; \\ E-mail:omunzuroglu@firat.edu.tr
}

(Received 30 November, 2000)

\begin{abstract}
In this study, shocks of cold at the levels of 5, 3 and $1{ }^{\circ} \mathrm{C}$ have been applied to the 6-days old chickpea (Cicer arietinum L.) plants. Next, having been left to grow for 72 hours under long day photoperiod circumstances at $25^{\circ} \mathrm{C}$, the length of their root and epicotyl have been measured at certain intervals. Moreover, the protein contents of the plants exposed to low temperature shocks $\left(1^{\circ} \mathrm{C}\right)$ have been identified in connection with their controls.

According to the results obtained, the low temperature shocks have prevented the length of the roots and epicotyl to a large extent. It is observed that the lower the temperature is, the more the plant's growth is prevented. It has also been observed that the cold stress caused by the low temperature application might be reversible. The plants get rid of this stress later in low temperatures than in high ones. The low temperature application (1 ${ }^{\circ} \mathrm{C}$ ) has also considerably reduced the total protein amount.
\end{abstract}

Key words: chickpea (Cicer arietinum L.), low temperature shock (chilling effect), plant growth, protein

\section{INTRODUCTION}

It is accepted that water is the most limiting factor in the productivity of plants, while the most limiting factor in geographical distribution is low temperature. This limitative effect of low temperature is caused by freezing and chilling. Both freezing and chilling give very important damages to agricultural plants almost everywhere in the world.

Plants show high differences according to their sensibilities to low temperature. Especially plants grown in tropical and subtropical regions can be hurt and also die in low temperatures up to $20^{\circ} \mathrm{C}$ that is above the point of freezing of tissue (Graham and Patterson 1982). As an example, it is claimed that a $1{ }^{\circ} \mathrm{C}$ fall in the world temperature can cause a $40 \%$ decrease in rice production and can also change the distribution of some plants (Nielsen and Orcutt 1996). The effects on plants of freezing and chilling are extremely different from each other. By freezing; in extracellular areas, ice-crystals are formed, protoplasmic water is gone out of the cell and 
it is added to the extracellular ice-crystals. Chilling-sensitive plants this dissolution of ice-crystals gives damage to membranes and other cell particles in plants that are not enduring to cold (Hopkins 1995). Chilling, which seen in low temperatures where there is no freezing, affects growing, developing and metabolic processes depending on them negatively in plants. It is reported that chilling stress at plants causes leaf and fruit to get hurt, leaves to curling abnormally and crack at the body, to separate, dry and decay from the top to the roots; and it also results in chlorosis in plants (Wilson 1987, Saltveit and Morris 1990, Haldimann 1998).

The metabolic symptoms of being damaged by cold come out as a further change in the structure of the membrane and its contents (Williams et al. 1988, Raison and Orr 1986, Lynch 1990) a breakdown in protoplasm streaming, a decrease in protein synthesis and a change in the mechanism of protein synthesis (Hopkins 1995), electrolytes' leaking out of the cell (Wilson and McMurdo 1981, Palta and Weiss 1993), and an inhibition in photosynthesis and respiration (Lewitt 1980, Wilson and McMurdo 1981, Markhart 1986).

The chickpea, reported (Van der Maesen 1987) as originated in the southeast of Turkey, grows in tropical and subtropical regions. Sunny dry climates, northern hemisphere's autumn and winter subtropical climates are mostly suitable for the chickpea (Smithson et al. 1985). It is relatively sensitive to cold. Freezing causes important loss of production. According to the data collected in 1998 (DSE 1998) in our country, it is sowed in $2,166,000$ hectares and gained 2,077,000 tons products. In this study, the effects of low temperature on the root and epicotyl growth after germination are researched on the kind of chickpea agricultured in our country (Cicer arietinum L.). Further, the effects of cold shocking on the amount of total protein are found out. Consequently, the tolerance of the chickpea, which is one of our country's important agricultural products, early growing states to low temperature is tried to be enlightened to some extent.

\section{MATERIAL AND METHODS}

In this study, the chickpea, which is sensitive to cold, Cicer arietinum L. species, agricultured in our country, is used as the material. Seeds are taken from Elazığ Agriculture Administrative Province Former Education and Training Office. 
The chickpea seeds are left in $25^{\circ} \mathrm{C}$ tap water in a dark environment for nine hours which is used as a swelling up circumstance. Swollen up seeds are sowed in Petri dishes, having the diameter of $11 \mathrm{~cm}$, which are filled with two-layered filter paper and $10 \mathrm{ml}$ tap water, in the way that their ventral sides are in connection with the filter paper. After sowing, the seeds are left to germination in dark with $25 \pm 1^{\circ} \mathrm{C}$ temperatures. At the end of this time, the seeds that become grassy, and uniformity selection applied are transplanted between the wet filter papers, that are placed in 1,000 $\mathrm{cm}^{3}$ beher glasses, twist vertically (Munzuroğlu and Baltepe 1993). These beher glasses, prepared like this, are put into plant growing cabins as 6 groups (each group consisting of 30 seedling) and in $25^{\circ} \mathrm{C}$, with $15 \mathrm{~h}$ long day photoperiod, under 1,700 lux light intensity, and seedlings are grown by leaving them there for 4 days. Consequently, after about 6 days from wetting, seedlings will be exposed cold-shocked were obtained for morphological observations such as root and coleoptile growing and total protein analyses.

\section{The measuring of length of root and epicotyls}

The plants in the first four groups of the 6 group beher glasses in plant growth cabinet were used for morphological observations. From these 4 beher glasses, the first one was left to cold shock for nine hours in dark at 5 ${ }^{\circ} \mathrm{C}$, the second at $3{ }^{\circ} \mathrm{C}$ and the third one at $1{ }^{\circ} \mathrm{C}$. The fourth group (control group) was left in dark at $25^{\circ} \mathrm{C}$ during the same period. At the end of this period, each root and epicotyl length of the seedlings of each group were measured as different from others. Later, all the beher glasses were put into the plant growth cabinet and left for 72 hours under 1,700 lux light intensity with 15 hours long day photoperiod in $25 \pm 1^{\circ} \mathrm{C}$. By the time, according to the photoperiod, the length of root and epicotyls of seedlings was measured and recorded through specific time intervals ( 9 hours, 15 hours). Obtained findings were given in histogram. Moreover, the increase rates of root and epicotyl lengths were determined in percentage, considering the lengths that were found out immediately after the cold shock.

\section{Total protein determination}

The seedlings, in the beher glasses that belong to the last two groups left for 4 days in plant growth cabinet, were used for protein analyses. As the inhibition in root and epicotyl lengthening can be seen as most evi- 
dently in $1{ }^{\circ} \mathrm{C}$, the cold shock for the seedlings was applied at this temperature. One of these 2 seedling groups (control group) was left in $25{ }^{\circ} \mathrm{C}$ in dark for 9 hours. The other (experiment group) is left in $1^{\circ} \mathrm{C}$ cold shock in dark at the same period. At the end of this period, ten seedlings from each control and experiment group that seem homogeneous were selected. After removing the cotyledons of the seedlings, by weighing the root and epicotyls, their total raw weights were determined. (The total weight of the control group was $2.75 \mathrm{~g}$, the total weight of the group experiment was $2.65 \mathrm{~g}$ ).

From these seedlings protein extraction was done following Larson and Beevers (1965) as is told by Ross (1974). The amount of those proteins extracted was found out by Lowry et al. (1951). The results were given in histograms as the tissues per fresh weight $(\mathrm{g})$ to $\mathrm{mg}$.

All the experiment series were repeated 3 times. The results are statistically analyzed, calculating the standard deviation (SD) of the mean.

\section{RESULTS AND DISCUSSION}

The lengths of roots and epicotyls of chickpea seedlings measured after 9 hours cold shock are given in Figures 1-3 (0 is the time point in the figures). In these figures, the lengths, measured at different periods, left at $25 \pm 1{ }^{\circ} \mathrm{C}$ and cold-shocked with 15 hours long day photoperiod and under 1,700 lux light intensity for 72 hours, are indicated.

As it can be found out by examining the figures, cold-shocking blocks the lengths of the plants root and epicotyl to an important extent. This blocking comes into light much clearly when it is parallel to the decreasing temperature. Furthermore, the plant can get rid of the effect of the shock later under low temperature. For example, in the plants cold-shocked under $5{ }^{\circ} \mathrm{C}$, in the first 24 hours root length $52 \pm 3.2 \mathrm{~mm}$ increases to $58 \pm 4.1$ $\mathrm{mm}$, epicotyl length $19 \pm 3.2 \mathrm{~mm}$ increases to $20 \pm 3.6 \mathrm{~mm}$ (Fig. 1). At the same period, these values for $3^{\circ} \mathrm{C}$ cold-shocked plants become $55 \pm 3.1 \mathrm{~mm}$ $-59 \pm 3.1 \mathrm{~mm}$ for the root and $20 \pm 1.2 \mathrm{~mm}-20 \pm 1.2 \mathrm{~mm}$ epicotyl, for $1{ }^{\circ} \mathrm{C}$ cold-shocked plants it becomes $53 \pm 2.4 \mathrm{~mm}-53 \pm 2.4 \mathrm{~mm}$ for the root and $19 \pm 0.8 \mathrm{~mm}$ for epicotyl (Fig. 3). These parameters, for the control group plants, become $54 \pm 3.1 \mathrm{~mm}-84 \pm 3.1 \mathrm{~mm}$ for the root and $19 \pm 2.1 \mathrm{~mm}-$ $25 \pm 4.1 \mathrm{~mm}$ for the epicotyl (Fig. 1). After 33 hours from the cold-shock, in the control group plants' roots a $72.2 \pm 5 \%$, and in the epicotyls a $47.3 \pm 4.4 \%$ lengthening occur (Fig. 4). These values for $5,3,1{ }^{\circ} \mathrm{C}$ cold-shocked plants' roots and epicotyls are recorded as $21.2 \pm 2.7 \%-51.8 .4 \pm 2.3 \% ; 16.3 \pm 1.4 \%$ - 
$10.0 \pm 1.6 \%$ and $9.4 \pm 2.1 \%-5.2 \pm 1.2 \%$ in an order. For each temperature, it is observed that after a while plants get rid of this effect partially.

Although they cannot reach the growth rate of the plants that are not cold-shocked, these plants reach the growth and developing process counted as normal. As an example, in $5{ }^{\circ} \mathrm{C}$ cold-shocked plants, after 72 hours, $83.6 \pm 7.1 \%$ lengthening in root and $84.2 \pm 8.4 \%$ lengthening in epicotyls occur (Fig. 5). These values are recorded as, in an order, $72.2 \pm 5.9 \%-$ $75.0 \pm 5.8 \% ; 52.8 \pm 6.2 \%-57.8 \pm 6.3 \%$ for the $3{ }^{\circ} \mathrm{C}$ and $1{ }^{\circ} \mathrm{C}$ cold-shocked plants' roots and epicotyls. These data show us that the temperatures applied on the experiment materials are not in frozen but cooling effect.

The protein amounts of the chickpea seedlings, that are $1{ }^{\circ} \mathrm{C}$ coldshocked, are given in Figure 6. Comparing with the control group plants, it is stated that the amount of total protein in experimental plants is $28.1 \pm 12$ $\mathrm{mg}$ per fresh tissue gram where as it is $49.1 \pm 2.4 \mathrm{mg}$ in control plants. These results show the cold-shock lessens the protein amount in an excessive rate.

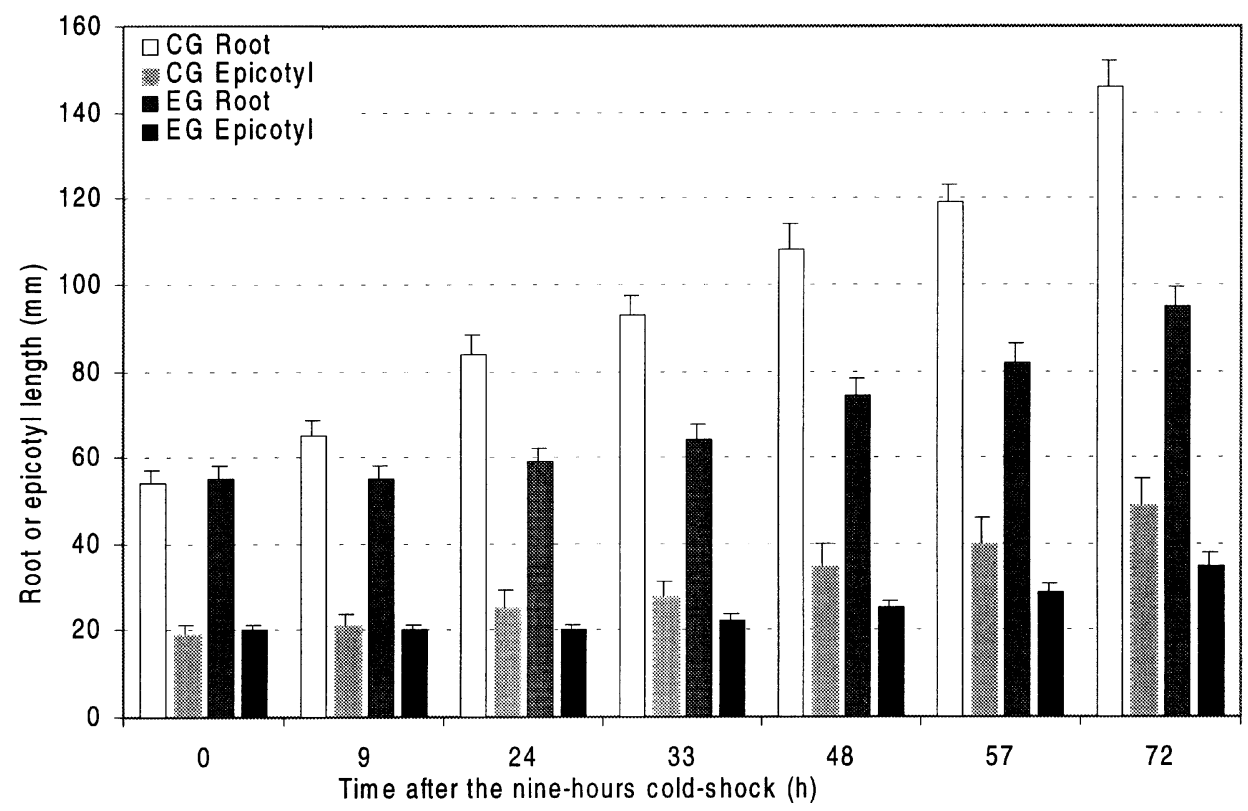

Fig. 1. Root and epicotyl lengths, that are measured at different periods, of the chickpea seedlings, cold-shocked for nine hours in $5{ }^{\circ} \mathrm{C}$ and the left growing in $25 \pm 1{ }^{\circ} \mathrm{C}$, under 1,700 lux light intensity with 15 hours long-day photoperiod. CG: Control group, EG: experiment group 
As it is known, various kinds of plants living in the environment of warm climates can get damaged when they are exposed to low temperature the nonfreezing freezing point. This damage increases in the early growth phases, with food and water scarcity and under high light intensity (Kratsch and Wise 2000). However, if the chilling level is not very intensive and long lasting, when the plant is left in warm temperature, the processes, caused damages, turn into their normal states and the damage does not go on in the plant. This state is brought up clearly in the studies of acquiring endurance to cold (Larcher and Bauer 1981). Chilling affects many physiological and biochemical events negatively. One of the initial negativity is the spoiling of the membrane structure and decreasing enzyme activity. In some plants sensitive to chilling, it is reported that the enzymes acting in photosynthesis and respiration are affected (Du et al. 1999, Graham and Patterson 1982) and ATP-ase activity lessens (Palta and Weiss 1993).

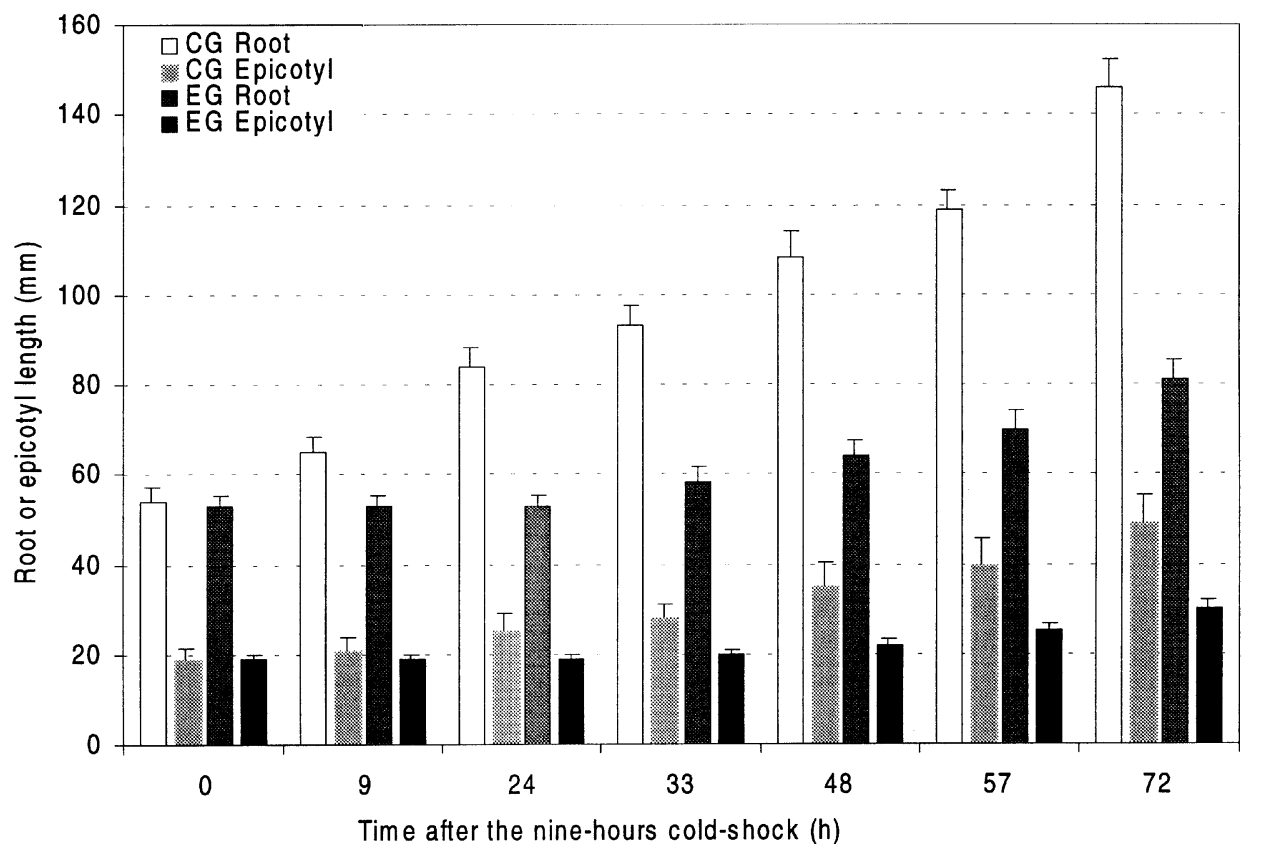

Fig. 2. Root and epicotyl lengths, that are measured at different periods, of the chickpea seedlings, cold-shocked for nine hours in $3{ }^{\circ} \mathrm{C}$ and the left growing in $25 \pm 1{ }^{\circ} \mathrm{C}$, under 1,700 lux light intensity with 15 hours long-day photoperiod. CG: Control group, EG: experiment group 


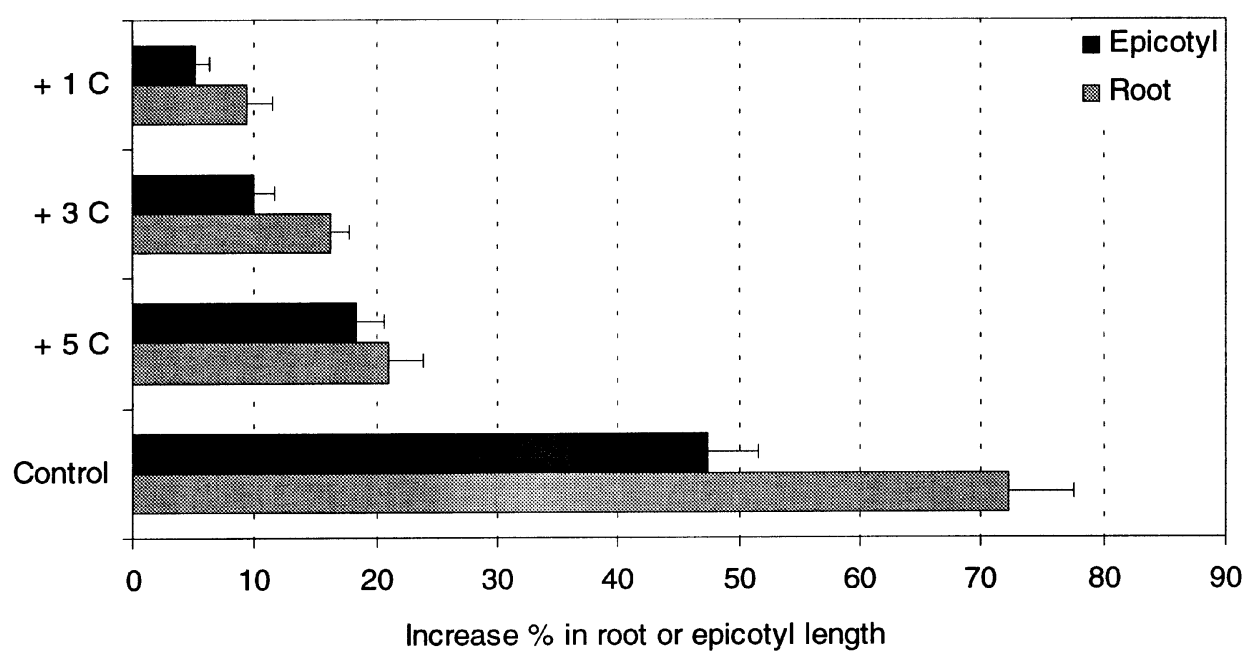

Fig. 3. Root and epicotyl lengths, that are measured at different periods, of the chickpea seedlings, cold-shocked for nine hours in $1{ }^{\circ} \mathrm{C}$ and the left growing in $25 \pm 1{ }^{\circ} \mathrm{C}$, under 1,700 lux light intensity with 15 hours long-day photoperiod. CG: Control group, EG: experiment group

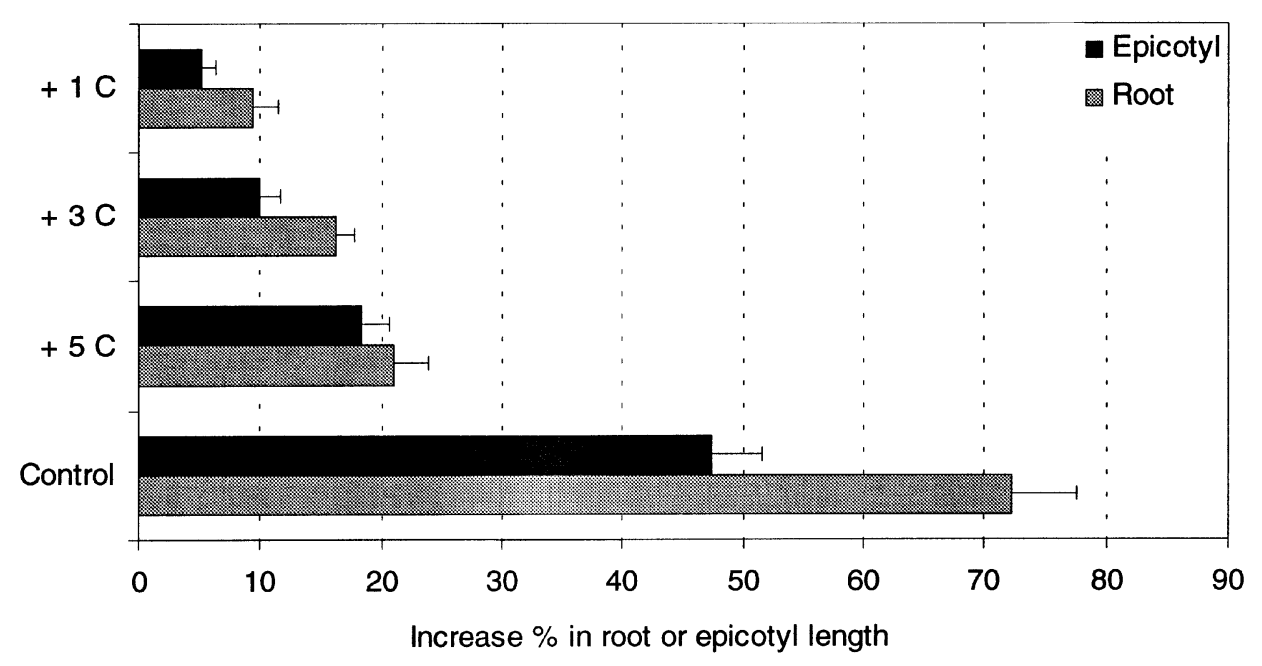

Fig. 4. Increase \% rates of root and epicotyl lengthening, identified after 33 hours, of the chickpea seedlings, cold-shocked for nine hours in 5,3 and $1{ }^{\circ} \mathrm{C}$, and then left growing in $25 \pm 1^{\circ} \mathrm{C}$, under 1,700 lux light intensity with 15 hours long-day photoperiod 


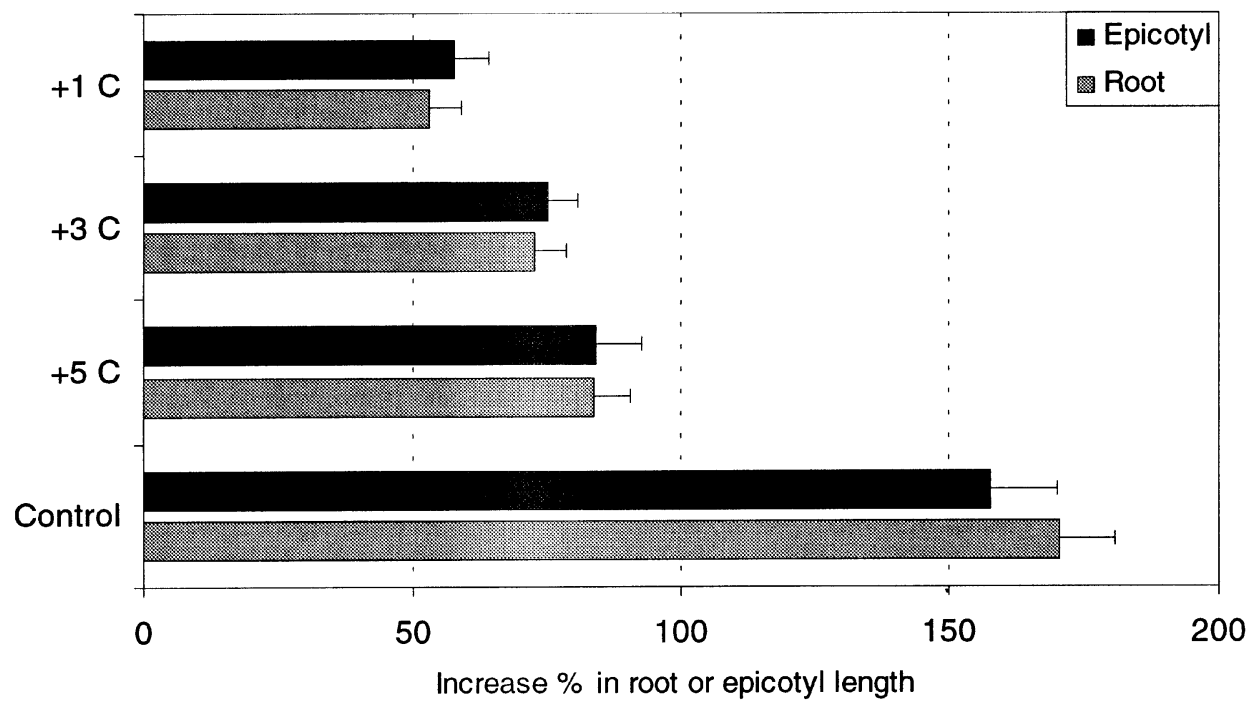

Fig. 5. Increase \% rates of root and epicotyl lengthening, identified after 72 hours, of the chickpea seedlings, cold-shocked for nine hours in 5,3 and $1{ }^{\circ} \mathrm{C}$, and then left growing in $25 \pm 1{ }^{\circ} \mathrm{C}$, under 1,700 lux light intensity with 15 hours long-day photoperiod

It is observed that in the $5^{\circ} \mathrm{C}$ cold-shocked for 12 hours tomato cotyledons, the mitochondria are moderately, the chloroplasts are highly damaged (Ilker et al. 1979). As the membranes are damaged, an unbalance occurs between the enzymes connected to the membrane and the enzymes not connected to the membrane. It is seen that some chilling-sensitive plants accumulate ethyl alcohol, acetaldehyde and alanine. In addition,

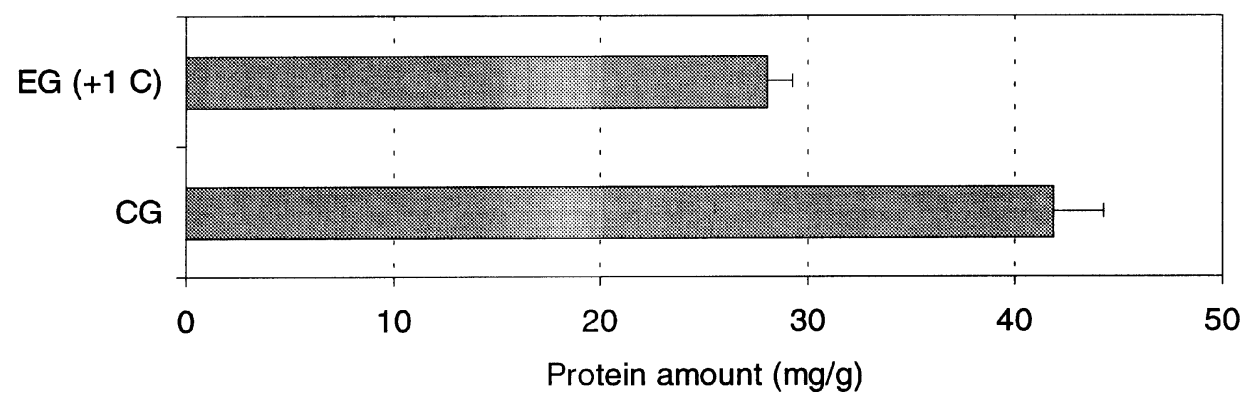

Fig. 6. The protein amount of 6-days chickpea seedlings, that are cold-shocked for nine hours in $1^{\circ} \mathrm{C}(\mathrm{EG})$ and not $(\mathrm{CG})$, measured as milligram per fresh tissue's gram just after the application. CG: Control group, EG: experiment group 
this is an evidence of the decrease in mitochondria enzyme activity. It is claimed that there will be a decrease in ATP synthesis because of the unbalance in mitochondria and glycolysis systems and membranes important in ATP formation (Nielsen and Orcutt 1996). It is stated that in the plants under the chilling stress stomates are closed and the entrance of $\mathrm{CO}_{2}$ is hindered (Wilson 1987) the activity of enzymes breaking the starch and the skill of carbohydrate transfer sieve tubes are decreased (Graham and Patterson 1982). From another point, it is believed that there is ABA's role in the herbaceous plant tissues are getting used to cold. It is reported that in various plant kinds, endogen ABA level increases excessively with the application of cold (Mohapatra et al. 1988, Kosakovskaya and Maidebura 1989). ABA is a regulator that generally delays or stops growth and development. With the application of ABA, the cell division and cell lengthening are reduced (Barlow and Pilet 1984). Transcription, translation and various protein synthesis are hindered (Varty et al. 1982, Jacobsen 1977). Moreover, it is known that with the cold application, total protein amount decreases (Sabehat et al. 1996) cold acclimation proteins (CAP) are synthesized (Kung et al.1998, Gilmour et al. 1988).

All of these data are in the entity of explanation of the decrease in total protein level and the inhibition in root and epicotyl lengthening of our experimental materials, because of the fact that the chickpea is a kind proportionally sensitive to cold. The cold-shock hinders the growth and development as it causes a few of the mentioned data above. There is connection between various physiological, biochemical and biophysical events for the damage and symptoms in chilling-sensitive plants. There are two claims for these connections. According to the view claimed by Raison and Orr (1990), there is only one primary event that causes chilling damage in plants (probably the spoiling of membrane structure). The secondary events rooted from this primary event causes the total chilling damage. The other claim (Naylor 1983) rejects the idea that there is one primary event responsible for the beginning of the chain of the events causing the chilling damage. According to this view, chilling temperatures can cause important effects on any of the enzymes in metabolic process or the function of other enzymes in process. And mainly, it can demolish the balance between many metabolic processes. As a result, many metabolic events can be affected at the same time. However, according to both views, chilling stress spoils the membrane structure. It decreases ATP production and enzyme activity. The negative effect of the decrease in enzyme activity on many metabolic events is inevitable for the chilling-sensitive plants. In our 
study, the damage of the chilling not being long-lasting and the plants turning into their growth and development processes are normal results. Because of the fact, that the cold-shocks applied are not at freezing level and moreover, the shocks are applied in short periods like only 9 hours.

Consequently, short period and not freezing cold-shocks inhibit the root and epicotyl lengthening of the chickpea plant in an excessive amount. It decreases the total protein amount. It is observed that this inhibitive effect increases parallel to the decrease in temperature. It is found out that the chilling stress caused by the cold is reversible. In this study, the chickpea's, which is among important agricultural products, tolerance to low temperatures in its early growing stages is tried to be explained to some extent. In all the countries, the researches on the negative effects caused by this stress factor, which concerns plant production directly, will provide excessive profit. We are in conviction that our research will add to the studies on this subject to some extent.

\section{REFERENCES}

Barlow, P. W. and Pilet, P. E. (1984): The effect of abscisic acid on cell growth cell division and DNA synthesis in the maize root meristem. - Physiol. Plant. 62: 125-132.

DSE (1998): Devlet Statistik Enstitüsü. - Tarımsal Yap ve Üretim.

Du, Y.-C., Nose, A. and Casino, K. (1999): Effect of chilling temperature on photosynthetic rates, photosynthetic enzyme activities and metabolite levels in leaves of three sugarcane species. - Plant Cell and Environment 22(3): 317-324.

Gilmour, S. L., Hajela, K. R. and Thomashow, M. F. (1988): Cold acclimation in Arabidopsis thaliana. - Plant Physiology 87: 745-750.

Graham, D. and Patterson, B. D. (1982): Responses of plants to low, nonfreezing temperatures: proteins, metabolism, and acclimation. - Ann. Rev. Plant Physiology 33: 347-372.

Haldimann, P. (1998): Low growth temperature induced changes to pigment composition and photosynthesis in Zea mays genotypes differing in chilling sensitivity. - Plant Cell and Environment 21(2): 200-208.

Hopkins, W. G. (1995): Introduction to plant physiology. - John Wiley and Sons, Inc., New York, pp. 431-435.

Ilker, R., Breidenbach, W. and Lyons, J. M. (1979): Sequence of ultrastructural changes in tomato cotyledons during short periods of chilling. - In: Lyons, J. M., Graham, D. and Raison, J. K. (eds): Low temperature stress in crop plants: The role of the membrane. Academic Press, New York, pp. 97-113.

Jacobsen, J. V. (1977): Regulation of ribonucleic acid metabolism by hormones. - Ann. Rev. Plant Physiology 28: 537-564.

Kosakovskaya, I. V. and Maidebura, E. V. (1989): Phytohormonal regulation of adaptive processes in plants: Role of abscisic acid in resistance to stresses. - Fiziol. Biochim. Kul'turn. Rast. 21(4): 315. 
Kratsch, H. A. and Wise, R. R. (2000): The ultrastructure of chilling stress. - Plant Cell and Environment 23(4): 337-350.

Kung, C.-C. S., Yeh, K.-W., Lin, C.-Y. and Chen, Y.-M. (1998): Characterization of a pea gene responsive to low temperature. - Bot. Bull. Acad. Sinica 39(1): 9-15.

Larcher, W. and Bauer, H. (1981): Ecological significance of resistance to low temperature. - In: Lange, O. L., Nobel, P. S., Osmond, C. B. and Ziegler, H. (eds): Encyclopedia of plant physiology. New series, Vol. 12A, pp. 403-437.

Larson, L. A. and Beevers, H. (1965): Amino acid metabolism in young pea seedlings. Plant Physiology 40: 424-432.

Lewitt, J. (1980): Responses of Plant to Environmental Stresses. Vol. 1. - Academic Press, New York.

Lowry, O. H., Rosebrough, N. J. and Randall, R. J. (1951): Protein measurement with the folin phenol reagent. - J. Biol. Chemistry: 193-265.

Lynch, D. V. (1990): Chilling injury in plants: The relevance of membrane lipids. - In: Katterman, F. (ed.): Environmental injury to plants. Academic Press, New York, pp. 17-34.

Markhart III, A. H. (1986): Chilling injury: A review of possible causes. - Hart Science 21: 1329-1333.

Mohapatra, S. S., Wolfraim, L., Poole, R. J. and Dhindsa, R. S. (1988): Molecular cloning and relationship to freezing tolerance of cold-acclimation-specific genes of alfalfa. - Plant Physiology 89: 375-380.

Munzuroğlu, O. and Baltepe, S. (1993): Trafik araçlarından kaynaklanan hava kirlenmesinin buğday (Triticum aestivum L.) bitkisi üzerindeki etkilerinin araştırılması. - F. $\ddot{U}$. Fen ve Müh. Bilimleri Dergisi 5(2): 93-104.

Naylor, A. W. (1983): The many faceted problem of chilling injury. - In: Purvis, A. (ed.): Molecular and physiological aspects of stress in plants. Proceedings of the Southern Section of the American Society of Plant Physiology. University of Tennessee, Knoxville,TN., pp. $55-74$.

Nielsen, E. T. and Orcutt, D. M. (1996): Physiology of plants under stress, abiotic factors. - John Wiley and Sons, Inc., 605 Third Avenue, New York, pp. 486-511.

Palta, J. P. and Weiss, L. S. (1993): Ice formation and freezing injury: an overview on the survival mechanisms and molecular aspects of injury and cold acclimation in herbaceous plants. - In: Li, P. H. and Christersson, L. (eds): Advances in cold hardiness. CRC Press, Boca Raton, FL, pp. 143-173.

Raison, J. K. and Orr, G. R. (1986): Phase transitions in liposome's formed from polar lipids of mitochondria from chilling-sensitive plants. - Plant Physiology 81: 807-811.

Raison, J. K. and Orr, G. R. (1990): Proposals for a better understanding of the molecular basis of chilling injury. - In: Wang, C. Y. (ed.): Chilling injury of horticultural crops. CRC Press, Boca Raton, F.L., pp. 145-164.

Ross, W. C. (1974): Plant physiology laboratory manual. - Wands Worth Publishing Company, Inc., Belmont, California.

Sabehat, A., Weiss, D. and Lurie, S. (1996): The correlation between heat-shock protein accumulation and persistence and chilling tolerance in tomato fruit. - Plant Physiology 110: 531-537.

Saltveit, M. E. and Morris, L. L. (1990): Overview on chilling injury of horticultural crops. - In: Wang, C. Y. (ed.): Chilling injury of horticultural crops. CRC Press, Boca Raton, FL, pp. 3-15. 
Smithson, J. B., Thompson, J. A. and Summerfield, R. J. (1985): Chickpea (Cicer arietinum L.). In: Summerfield, R. J. and Roberts, E. H. (eds): Grain legume crops. Collins, London, UK, pp. 312-390.

Van der Maesen, L. J. G. (1987): Cicer L. Origin, history and taxonomy of chickpea. - In: Saxena, M. C. and Singh, K. B. (eds): The chickpea. C.A.B. International Cambrian News Ltd., Aberystwyth, UK, pp. 11-34.

Varty, K., Arreguin, I. B., Gomez, T. M., Lopez, T. P. J. and Gomez, L. M. A. (1982): Effects of abscisic acid and ethylene on the gibberellic acid-induced synthesis of $\alpha$-amylase by isolated wheat aleurone layers. - Plant Physiology 73: 692-697.

Williams, J. P., Khan, M. U., Mitchell, K. and Johnson, G. (1988): The effect of temperature on the level and biosynthesis of unsaturated fatty acids in diaclyglycerols of Brassica napus leaves. - Plant Physiology 87: 904-910.

Wilson, J. M. (1987): Chilling injury in plants. - In: Grout, B. W. W. and Morris, G. J. (eds): The effects of low temperatures on biological systems. Edward Arnold, London, pp. 272-292.

Wilson, J. M. and McMurdo, A. C. (1981): Chilling injury in plants. - In: Morris, G. J. and Clarke, A. (eds): Effect of low temperatures on biological membranes. Academic Press, New York, pp. 145-172. 